\title{
A FELSŐOKTATÁSBAN RÉSZT VEVŐ HALLGATÓK FÖLDRAJZI MOBILITÁSA ${ }^{+}$
}

\author{
TÖZSÉR ANETT* - PÉTERFI PETRA \\ Nemzetstratégiai Kutatóintézet
}

A kutatás fókuszában a Kárpát-medencei magyar felsőoktatási intézményeket érintő hallgatói pályák feltérképezése áll. E témakör fö kérdése, hogy milyen mértékben és milyen minőségben valósul meg a Kárpát-medencei magyar felsőoktatásban a hallgatói mobilitás. A kvalitatív kutatásaink alapján sikerült feltérképeznünk a Kárpát-medencei magyar felsőoktatási intézményeket érintő hallgatói pályákat. A kutatás keretében elemeztük a hallgatók mobilitási hajlandóságát, attitüdjét, a mobilitás lehetséges akadályait, valamint az ezekre kínálkozó megoldási alternatívákat is feltérképeztük.

Kulcsszavak: felsőoktatás, mobilitás, Kárpát-medence

The focus of the research is the mapping of students' career paths outside the Carpathian Basin and of Hungarian higher education institutions in the Carpathian Basin. The main question in this topic is the extent and quality of student mobility in Hungarian higher education in the Carpathian Basin. Through the methodology of qualitative research, we have been able to map in detail the depths of student careers in Hungarian higher education institutions in the Carpathian Basin. Within the framework of the research, we analysed the students' willingness to move, their attitudes, the possible obstacles to mobility, and the solutions available to them.

Keywords higher education, mobility, Carpathian Basin

\section{A felsőoktatási mobilitás \\ Hallgatói mobilitás a nemzetközi térben}

$R$ édei (2009) felsőoktatási tanulmányi mobilitásról alkotott definíciója szerint a tanulmányi mobilitás fogalmán egy adott országból külföldre vagy külföldröl az adott országba irányuló fizikai mobilitást értünk, amelynek célja felsőoktatási, képzési, illet-

Levelező szerző: Dr. Tőzsér Anett, Nemzetstratégiai Kutatóintézet, 1054 Budapest, Nagysándor József u. 8. E-mail: anett.tozser@nski.gov.hu

+ Jelen tanulmány az EFOP-3.10.1-17-2017-00002 „Az oktatási struktúrák Kárpát-medencei makroregionális együttműködését támogató kutatások” című projekt keretein belül, a „Kutatások, vizsgálatok a felsőoktatásra és köznevelésre hatást gyakorló tényezők, tendenciák megismerése érdekében” témában született eredmények alapján készült. 
ve képzéshez kapcsolódó kutatási céllal szervezett programokon történő szervezett vagy egyéni részvétel.

A diákmobilitás az utazás irányának függvényében lehet kiutazó, illetve beutazó, amely export-, illetve importtevékenységként is megfogalmazható. Ezenfelül a tanulmányok időtartama szerint megkülönböztethető a teljes diplomát nyújtó képzés, illetve a részképzés (Berács 2011).

$\mathrm{A} z$ ezredfordulót követő első évtized végére körülbelül 130 millió - közöttük 2,6 millió külföldi állampolgárságú - diák tanult a világon felsőoktatásban. Egyes becslések szerint a felsőoktatásban tanulók száma 2025-re 250 millióra, a külföldi állampolgárságú tanulóké pedig 8 millióra növekedhet, amely a külföldi hallgatók számának, az általában vett hallgatók számánál nagyobb ütemü növekedésére utal (Berács 2010). A tanulási célú mobilitás a világban térbeli koncentrációt mutat, amelynek pólusát a legnagyobb befogadó országok, tehát az USA, Kanada, Ausztrália jelentik. A befogadás mértéke azonban jellemzően nem arányos a kibocsátással (Rédei 2009).

A 20. században a gazdasági fejlettség különböző szakaszaiban levő országok és régiók a tudomány és a felsőoktatás fejlettsége szempontjából drámai változáson mentek át. Az évszázad első felében még meglévő előnyét Európa elveszítette Észak-Amerikával szemben, majd a század végén már érzékelhetővé vált, hogy a dinamikusan fejlődő ázsiai országok (Japán, Kína, Koreai Köztársaság, Hongkong, Szingapúr stb.) mind a hallgatószámban, mind a kutatási produktumokat illetően előretörtek. Ebben a helyzetben Európa és az egyes országai külön-külön is lépéseket tettek a szerepvesztés mérséklésére, ugyanakkor nem nagy sikerrel. Ebben a helyzetben új megvilágításba kerül a nemzetköziesedés folyamata, rendszere a felsőoktatási intézményekben (Berács 2011).

$\mathrm{A} z$ USA, valamint Kína egyaránt stratégiai ágazatnak és a nemzetközi versenyképesség egyik fokméröjének tekintik a felsőoktatást, illetve azt, hogy képesek legyenek külföldi hallgatókat fogadni. A külföldi hallgatókat ösztöndíjakkal is támogatják. Az USA-ban több mint 600000 külföldi hallgató tanul, akik közül a legtöbben (20\%) - a 2007/2008-as tanév adatai szerint - üzleti képzésen tanulnak. Kína is kimagasló helyen szerepel az üzleti képzés tekintetében (8,9\%), azonban az ázsiai országban a bölcsészettudomány jelentős mértékben vezet, megközelítőleg 70 százalékkal (Berács 2011).

A z Európai Unió tagországaiban a felsőoktatásban tanuló hallgatók 10-15\%-a nevezhető mobilnak, tehát a hallgatók ekkora aránya tölt el bizonyos mértékü időt külföldön felsőfokú tanulmányainak ideje alatt (Tóth 2005). Az OECD országokban, a diplomát nyújtó képzésekben 2015-ben Új-Zéland, az Egyesült Királyság és Ausztrália, illetve Svájc és Ausztria fogadtak magas arányban külföldi hallgatókat, míg a küldő szerepben Szlovákia emelkedett ki (Kováts-Temesi 2018).

\section{Mobilitási programok Magyarországon}

A Tempus Közalapítvány által kezelt európai, regionális és nemzeti felsőoktatási programok és az általa végrehajtott projektek szorosan kötődnek az Európai Unió Európa 2020 stratégiájához, a Felsőoktatás Modernizációs Agendájához, valamint az Európai Felsőoktatási Térség elmélyítéséhez, megvalósításához (Dobos 2014).

A Tempus Közalapítvány tevékenységének középpontjában a magyar felsőoktatás nemzetköziesedésének támogatása áll, és alapvetően három, egymással szorosan összefüggő szinten fejti ki hatását, a szakpolitika, az intézmények és az egyének támogatása a 
következő programok segítségével: Erasmus+ (korábbi LLP/Erasmus, Erasmus Mundus, Tempus és Bologna tanácsadói hálózat), CEEPUS, valamint a Strukturális Alapokból finanszirozott Campus Hungary projektek. A megnevezett programok többségét a Tempus Közalapítvány több mint tíz éve koordinálja, a Campus Hungary projektek pedig 2012től egészítik ki a Közalapítvány nemzetköziesedést támogató tevékenységét. Az egyének támogatásának szintjén a Tempus Közalapítvány elsősorban a hallgatók és doktoranduszok külföldi mobilitását (tanulmányi részképzését, szakmai gyakorlatát, nyári egyetemen, intenzív programon való részvételét) támogatja, amellyel a hallgatók kompetenciafejlesztéséhez, valamint a leendő diplomások foglalkoztathatóságához egyaránt hozzájárul. Ezenfelül a Tempus Közalapítvány az oktatók, valamint a felsőoktatási intézmények alkalmazottjai számára is kínál (oktatási tevékenységre, nemzetközi kapcsolatok bővítésére, tapasztalatszerzésre, projektek előkészítésére) ösztöndíjakat. Az oktatók, illetve intézményi dolgozók számára kínált ösztöndíjak jelentős mértékben hozzájárulnak a humánerőforrás-fejlesztésen túl az intézmények kapacitásának bővítéséhez, illetve nemzetközi beágyazottságuk, valamint versenyképességük növeléséhez (Dobos 2014).

A 2015. évi adatok szerint az OECD-országokban, a diplomát nyújtó képzésekben az összes nemzeti hallgatóhoz - tanuljon otthon vagy külföldön - viszonyított külföldi hallgatók és a külföldön tanuló nemzeti hallgatók arányának tekintetében Magyarország körülbelül a középmezőnyben helyezkedik el Finnország és Svédország között, Németország társaságában (Kováts-Temesi 2018). A külföldi hallgatók aránya Magyarországon a közép-kelet-európai országok átlagához képest aránylag magas volt $(6,1 \%)$, azonban az európai uniós aránytól (7,7\%) elmaradt. A Magyarországon tanuló külföldi hallgatók számában 2005-2012 között közel 43\%-os növekedés volt tapasztalható (Duga 2016). A kezdeti - 1998 és 2006 közötti - időszakban Magyarország inkább a küldő szerepben jelent meg, ugyanis kétszer annyi magyar hallgató ment külföldre tanulni, mint ahány külföldi hallgató jött Magyarországra. A két görbe közötti olló a 2007-2013 közötti periódusban zárult be (Berács et al. 2015).

Az elmúlt öt évben a külföldi hallgatók száma dinamikusan nőtt, 39 százalékkal. Ennek eredményeként a külföldi hallgatók aránya elérte a 11,4 százalékot. A növekedés legnagyobb forrása a kormány által finanszírozott Stipendium Hungaricum program, amely a külföldi hallgatók 16 százalékát biztosítja (Kováts-Temesi 2018).

\section{Hallgatói mobilitás a Kárpát-medencében}

Az 1990-es évek elejétől az oktatás expanziója révén a környező országokban a társadalom szélesebb rétegei számára vált elérhetővé a bejutás a magyar felsőoktatásba. Egy 2004-es kutatás ${ }^{1}$ eredményei szerint a vizsgált mintában - azaz 2004 második félévében 3553 fö magyarországi továbbtanulást választó külhoni hallgató körében - jelentősen kimagaslott az értelmiségi családból származó fiatalok aránya; a legmagasabb a vajdasági, Magyarországon tanuló fiatalok körében volt. Az eredmények tükrében kijelenthető, hogy a magyarországi felsőoktatási rendszerbe való bekerülés esélyeit meghatározza a szülők iskolai végzettsége, amely jelenség részben magyarázható azzal, hogy ezek

„Határon túli hallgatók magyarországi tanulmányai” című kutatás, Erdei Itala vezetésével, a Határon Túli Magyarok Hivatala és a Márton Áron Szakkollégium támogatásában. 
a családok felülértékelik a magyarországi felsőoktatási diploma munkaerőpiaci esélyeit a szülőföldivel szemben, illetve a szülők azon irányú szándékával, hogy gyermekük kilépjen a szükebb társadalmi környezetükből (Erdei 2005).

A kutatás során vizsgált négy régió (Erdély, Felvidék, Vajdaság, Kárpátalja) között $a z$ anyagi háttér tekintetében jelentős különbségek voltak megfigyelhetőek. A legalacsonyabb jövedelmü szülői hátérrel az ukrajnai hallgatók rendelkeztek, legmagasabbal a szlovákiai származású diákok (Erdei 2005). Erdei (2005) elnevezésében az örökös csoportba sorolhatóak azok a fiatalok, akiknek családja gazdasági és kulturális tőkével egyaránt rendelkezik, s akiknél a család a fiatalok társadalmi státuszát céltudatos tőkebefektetéssel szeretné biztosítani. Az örökösök aránya mindegyik - a kutatásban vizsgált - régióban alapvetően magas volt, ami arra enged következtetni, hogy a gazdasági tőkével is rendelkező értelmiségi családok számára elérhetőbb a magyarországi továbbtanulás.

A határon túli magyar hallgatók magyarországi továbbtanulásának jelenlegi szakasza Magyarország Európai Unióhoz való csatlakozásával áll összefüggésben: a csatlakozás következtében az uniós jogszabályok értelmében 2004-től a szlovákiai (Erdei 2005), majd 2007-től a romániai hallgatók a magyar állampolgárokéval megegyező jogokkal tanulhatnak a magyar felsőoktatásban.

$\mathrm{A} z$ Erdei által vezetett 2004-es kutatás eredményei szerint elsősorban azok a fiatalok folytatták tanulmányaikat Magyarországon, akik már rendelkeztek mélyebb előzetes tapasztalattal az országról, illetve rokoni/baráti/érzelmi kötelék füzte őket hozzá. A felsőoktatási tanulmányok helyszínének választását a szülőföldtől függetlenül elsősorban saját döntésük befolyásolta, és csak másodsorban családjuk. A család anyagi helyzetének emelkedésével azonban növekszik a szülők befolyásoló ereje. A hallgatók többsége (76 százalékuk) már középiskolás korában, illetve néhányan már azt megelőzően, az általános iskolában eldöntötték, hogy Magyarországon szeretnének továbbtanulni (Erdei 2005).

Magyarországon a legnagyobb részképzést biztosító csereprogram az Erasmus, amelynek köszönhetően évente körülbelül 4000 fő megy külföldre és érkezik külföldről az országba. A magyarországi felsőoktatási intézmények határon túli képzési helyein tanulmányokat folytató hallgatók, az Erasmus és más mobilitási program keretében hallgatói jogviszonnyal rendelkező külföldi hallgatók, együtt jelennek meg a diploma megszerzését célul tűző hallgatókkal. A FIR-OSAP felsőoktatás-statisztikai adatgyüjtésben a kettős magyar állampolgárok abban az esetben minősülnek külföldi állampolgárnak, ha születési helyük országa nem Magyarország (Berács et al. 2017).

Romániából a 2013/2014-es tanévben 2253 hallgató érkezett, ez a 2014/2015-ös tanévben 1992, majd számuk a 2015/2016-os tanévben 1965-re csökkent, a 2016/ 2017-es tanévben pedig ismét 2054-re emelkedett. Szerbiából a 2013/2014-es tanévben 1543, a 2014/2015-ös tanévben 1517, a 2015/2016-os tanévben 1658 , a 2016/2017-es tanévben pedig már 1907 hallgató érkezett. Szlovákiából a 2013/2014-es tanévben 2350, a 2014/2015-ös tanévben 2120, a 2015/2016-os tanévben 2015, a 2016/2017-es tanévben pedig csak 1885 hallgató érkezett. Ukrajnából az imént említett három országhoz képest kevesebb hallgató érkezett: a 2013/2014-es tanévben 1169, a 2014/ 2015-ös tanévben 1080, a 2015/2016-os tanévben 1105, a 2016/2017-es tanévben pedig 1193 fö (Berács et al. 2017). 
Az elemzett négy év alatt a szomszédos országokból (Románia, Szlovákia, Szerbia és Ukrajna) érkezett hallgatók száma összesen 4 százalékot esett vissza. Mára a külföldi hallgatóknak csupán a negyedét teszik ki a külföldi, de magyar anyanyelvü hallgatók - ugyanez az arány tíz évvel ezelőtt még 50 százalék környékén ingadozott (Berács et al. 2017). A szomszédos országok magyar származású hallgatói egyedül Szerbiából jöttek nagyobb létszámban, mint korábban. Ennek olyan oka is van, hogy Erdélyben és a Felvidéken növekedett a helyben tanulás lehetősége magyar nyelven, míg a Vajdaságban erre csak korlátozottan van lehetőség (Kováts-Temesi 2018).

\section{Célok és módszertan}

A Kárpát-medencei magyar felsőoktatási intézményeket érintő hallgatói pályák feltérképezését célzó kutatás kvalitatív szakaszában, 2018. június 22. és 2019. január 15. között strukturált szakértői interjús vizsgálat lebonyolítására került sor. A 10 interjúalany a témában kompetens szakértőknek, ügyintézőknek, a mobilitási programok kapcsolattartóinak, illetve a HÖOK tagjainak köréből került kiválasztásra. Az interjúk felvétele elöre megírt kérdések, interjú-vezérfonal alapján, a félig strukturált interjú társadalomtudományos kutatási módszertani sztenderdjeinek megfelelően történt. Az interjúk nyolc esetben személyes találkozó során, 2 esetben pedig telefonon keresztül zajlottak.

A szakértői interjúk elsődleges célja a hallgatói és az oktatói-kutatói mobilitás minőségének, a kapcsolódó eredményeknek és hiányosságoknak a felmérése volt. A mintakeretet alkotó szakértők, intézményi ügyintézők, a mobilitási programok kapcsolattartói, illetve a HÖOK-tagok egyaránt számos olyan hallgatói és oktatói életúttal találkoztak már, amelyek ismeretében hasznos információkkal szolgálhatnak a vizsgált témakörben. A kombinált módszertan által részleteiben és mélységében sikerült feltérképeznünk a Kárpát-medencei magyar felsőoktatási intézményeket érintő hallgatói pályákat. Az interjúk keretében a hallgatók mobilitási hajlandóságát, attitűdjét, a mobilitás lehetséges akadályait, valamint az ezekre kínálkozó megoldási alternatívákat is feltérképeztük (NSKI 2019a, 2019b; Molnár 2019).

\section{A szakértői interjúk eredményei}

Az interjúk elemzése az alábbi témákat érintette: 1) általános tapasztalatok a mobilitási programok előnyeiről; 2) a tájékoztatás problémás területei; 3 ) a mobilitási programok szervezésének hátterében álló problémák; 4) a képzési struktúrához kapcsolódó problémák; 5) a kifelé irányuló mobilitás gátjai; 6) oktatói mobilitás.

A mobilitási programokra vonatkozó általános tapasztalatok kapcsán elmondható, hogy a magyar hallgatók alapvetően kis arányban tekinthetők mobilnak. A Magyarországról a szomszédos országok (Szlovákia, Románia és Szerbia) felsőoktatási intézményeibe irányuló mobilitás valamivel több mint 80 százaléka két egyetemre, a komáromi Selye János Egyetemre és a kolozsvári Babeș-Bolyai Tudományegyetemre összpontosul. Megállapítható továbbá az is, hogy a mobilitási programban való részvétel területi szinten eltérő: míg vidéken alacsonyabb szintű a mobilitás, addig a fővárosban jellemzően intenzívebb. Több vidéki felsőoktatási intézményben - a nagyobb vidéki egyetemváro- 
sok kivételével - lényegesen kevesebben jelentkeznek mobilitási programba, mint ahány hely van.

A tájékoztatás tekintetében általánosságban megállapítható, hogy azokat a diákokat a legnehezebb megszólítani, akik egyáltalán nem érdeklődnek a mobilitási programok iránt - nem mellesleg ez a legnagyobb arányú hallgatói csoport. Azonban az intézmények mind az offline, mind az online felületeken szorgalmazzák a folyamatos megjelenést. A mobilitási programokkal kapcsolatos információk megjelennek a hagyományos felületeken is, mint például a Neptunban, az egyetemi honlapokon, az egyetemen megtalálható plakátokon vagy akár közvetlenebb kommunikációs csatornákon (például közösségi oldalakon). Mindezek ellenére az a tapasztalatuk az interjúalanyoknak, hogy az információk legnagyobb arányban a tudatos hallgatókat érik el. A szakértők véleménye szerint a személyes találkozók és beszélgetések a legsikeresebbek a kommunikáció szempontjából.

A mobilitási programok szervezésének hátterében álló problémák felsőoktatási intézményenként változók lehetnek, és a karok között is jelentős különbségek vannak. A beszélgetések során nagyobb problémaként jelent meg, hogy az ügyintézési folyamat bonyolult, emiatt a hallgatóknak számos adminisztratív és bürokratikus kihívással kell szembenézniük. Ezenfelül gyakori problémaként jelentkezik, hogy a fogadó intézmények kevés angol nyelvű tárgyat hirdetnek meg, amely további nehézségeket okoz a hallgatók számára.

A képzési struktúrából adódó problémák között a tantervek rugalmassága/rugalmatlansága, a kreditek elismertethetősége és a részképzés ütemezhetősége meghatározó szempontként jelent meg. A magyar tantervek nehezen illeszthetők más európai tantervekhez, a curriculumok összeegyeztetése komoly nehézségeket jelent a kiutazni szándékozóknak. Emellett a szakértők arról is beszámoltak, hogy gyakran előfordul a hallgatók dupla terhelése, ugyanis ugyanazokból a kurzusokból a külföldi, valamint a hazai intézményben is le kell vizsgázniuk. A krediteket gyakran szabadon választható tárgyként ismerik csak el, ami pedig kredittúllépést is eredményezhet. A képzési struktúrából, a tantervek rugalmatlanságából adódó problémákra, valamint a kreditek elismertetésének nehézségeire megoldást jelenthetne, ha nagyobb lenne az együttmüködés a partneregyetemek között, illetve, ha olyan mobilitási ablak kerülne bevezetésre, amely a külföldi tárgyak széles skáláját elfogadó, választható tárgyspektrum kialakítását jelentené.

A kifelé irányuló mobilitás gátjaként három meghatározó tényezőt azonosítottunk. Az első akadályozó tényező a mobilitási programmal járó anyagi teher. A szakértők szerint az ösztöndíj összege nem elegendő ahhoz, hogy teljes mértékben fedezze a megélhetéshez szükséges költségeket. A második visszatartó faktor a megfelelö szintű nyelvtudás hiánya - amely fokozottan érvényesül a hátrányos helyzetü hallgatókra vonatkozóan -, valamint a nyelvismeretben való bizonytalanság érzése. Az interjúalanyok többsége megemlítette, hogy a hallgatók annak ellenére, hogy rendelkeznek a megfelelő szintü nyelvvizsgával, mégsem biztosak a saját nyelvtudásukban, így jelentős félelemként jelenik meg számukra a kiutazásnak ezen oldala. A harmadik és egyben talán a legjelentősebb hátráltató tényező a - már említett - kreditelismerés problémája.

A $z$ interjúelemzés utolsó blokkjában az oktatói mobilitással foglalkoztunk. Az interjúalanyok egybehangzó véleménnyel bírtak azzal kapcsolatban, hogy Magyarországon az oktatói mobilitás nagyon alacsony mértékben valósul meg, illetve jellemzően rövi- 
debb ideig, egy-két hétig tart. Az oktatói mobilitást hátráltató tényezők között a legmeghatározóbb a család jelenléte, valamint, hogy az anyaintézmények nehezen tudják megoldani hosszú távon az oktatók helyettesítését.

\section{Összefoglalás}

A kutatások alapján megállapítható, hogy a Magyarországon tanuló külföldi hallgatók számában 2005 és 2012 között közel 42 százalékos, az elmúlt 5 évben pedig 39 százalékos növekedés volt tapasztalható. Ennek eredményeként a külföldi hallgatók aránya elérte a 11,4 százalékot. A növekedés legnagyobb forrása a kormány által finanszírozott Stipendium Hungaricum program, amely a külföldi hallgatók 16 százalékát biztosítja.

Fontos fejlemény a határon túli magyar származású hallgatókat illetően, hogy míg a négy szomszédos ország (Románia, Szlovákia, Ukrajna, Szerbia) hallgatói 2009-ben 46,2 százalékot tettek ki a magyarországi felsőoktatásban, ez az arány 2017-ben 21,5 százalékra mérséklődött. A szomszédos országok magyar hallgatói egyedül Szerbiából jöttek nagyobb létszámban, mint korábban. Ennek oka lehet az, hogy Erdélyben és a Felvidéken növekedett a helyben tanulás lehetősége magyar nyelven, míg a Vajdaságban erre csak korlátozottan van lehetőség.

A Kárpát-medencei magyar felsőoktatási intézményeket érintő hallgatói pályák feltérképezését célzó kutatásunk kvalitatív szakaszában készült interjúk megerősítik azt a tényt, hogy a Magyarországról a szomszédos országok (Szlovákia, Románia és Szerbia) felsőoktatási intézményeibe irányuló mobilitás valamivel több mint 80 százaléka két egyetemre, a komáromi Selye János Egyetemre és a kolozsvári Babeș-Bolyai Tudományegyetemre összpontosul. Előbbi főleg határközeli pozíciójának, a tandíjmentesség lehetőségének, továbbá a képzésekre való könnyü bejutásnak köszönheti népszerűségét, míg utóbbi a speciális, a hazai képzési kínálatból hiányzó képzési programjaival tudja megnyerni magának a magyarországi hallgatókat, emellett Kolozsvár multikulturális jellege is vonzerőt jelenthet irányukba.

A szakértői interjúk alapján a Kárpát-medencében a hallgatói mobilitást akadályozó fö tényezők közé tartoznak az anyagi nehézségek és a kreditelismerés problémája. $\mathrm{A} z$ összes megkérdezett interjúalany kardinális kérdésként említette a képzési struktúrából, a tantervek rugalmatlanságából adódó problémakört. A beszélgetések alapján erre a problémás területre körvonalazódott néhány lehetséges megoldás, mint például a partneregyetemek közötti nagyobb együttmüködés, vagy a mobilitási ablak bevezetése, amely egy olyan választható tárgyspektrum kialakítását jelentené, amelyben a külföldi tárgyak széles skálája elfogadható.

\section{IRODALOM}

Berács J. (2010) A Magyarországon tanuló külföldi hallgatóság összetétele. In: Kurucz K. (ed.) Mobilitás Magyarországon. Lehetőségek és teendök. A 2010. január 19-i konferencia előadásainak összefoglalói. Budapest, Tempus Közalapítvány. pp. 15-20. 
Berács J. (2011) Diák mobilitás és Magyarország vonzereje. In: Berács J., Hrubos I. \& Temesi J. (eds) „Magyar Felsőoktatás 2010” Konferencia dokumentumok. NFKK FÜZETEK 6. pp. 44-55.

Berács J., Derényi A., Kádár-Csoboth P., Kováts G., Polónyi I. \& Temesi J. (2017) Magyar Felsőoktatás 2016. Stratégiai helyzetértékelés. Projekt jelentés. Budapest, Corvinus Egyetem Nemzetközi Felsőoktatási Kutatások Központja.

Berács J., Derényi A., Kováts G., Polónyi I. \& Temesi J. (2015) Magyar felsőoktatás 2014. Stratégiai helyzetértékelés. Nemzetközi Felsőoktatási Kutatások Központja.

Dовоs G. (2014, ed.) A felsőoktatási mobilitást akadályozó és ösztönző tényezök Magyarországon. Budapest, Tempus Közalapítvány.

Duga Zs. (2016) Az alumni szolgáltatások szerepe a hazai egyetemek müködésében. Doktori értekezés. Pécsi Tudományegyetem Közgazdaságtudományi Kar, Regionális Politika és Gazdaságtan Doktori Iskola.

Erdei I. (2005) Hallgatói mobilitás a Kárpát-medencében. In: Gábor K. \& Veres V. (eds) A perifériáról a centrumba. Az erdélyi fiatalok helyzetképe az ezredfordulón. Szeged-Kolozsvár, Belvedere Kiadó-Max Weber Tk Alapítvány. pp. 108-132.

Kováts G. \& Temesi J. (2018) A magyar felsőoktatás egy évtizede 2008-2017. NFKK Kötetek 2. Budapest, Corvinus Egyetem Nemzetközi Felsőoktatási Kutatások Központja.

Molnár G. (2019, ed.) Erdélyi érettségi ellenszélben. Beszámoló a székelyföldi és a partiumi magyar érettségi felkészítők oktatási versenyhátrányát és az érettségi felkészítő kísérleti oktatási program eredményességét vizsgáló többéves kutatási program eredményeiről. Kutatási Jelentés. Kárpát-haza Program. Budapest, Nemzetstratégiai Kutatóintézet.

NSKI (2019a) Kutatások, vizsgálatok a felsőoktatásra és köznevelésre hatást gyakorló tényezök, tendenciák megismerése érdekében. Kutatási jelentés. EFOP-3.10.1-17-2017-00002. Az oktatási struktúrák Kárpát-medencei makroregionális együttmüködését támogató kutatások kutatási projekt 1 . tevékenységcsoport 1 . fötevékenység tanulmánya. Budapest, Nemzetstratégiai Kutatóintézet.

NSKI (2019b) A tanulók és hallgatók földrajzi mobilitását feltáró kutatások. Kutatási jelentés. EFOP-3.10.1-17-2017-00002. Az oktatási struktúrák Kárpát-medencei makroregionális együttműködését támogató kutatások kutatási projekt 1 . tevékenységcsoport 2 . fötevékenység tanulmánya. Budapest, Nemzetstratégiai Kutatóintézet.

RÉDei M. (2009) A tanulmány célú mozgás. Reg-Info Kiadó, Budapest.

Tóтн É. (2005) Magyar hallgatók külföldön. Educatio, Vol. 14. No. 2. pp. 302-319.

A cikk a Creative Commons Attribution 4.0 International License (https://creativecommons.org/licenses/ by/4.0/) feltételei szerint publikált Open Access közlemény, melynek szellemében a cikk bármilyen médiumban szabadon felhasználható, megosztható és újraközölhető, feltéve, hogy az eredeti szerző és a közlés helye, illetve a CC License linkje és az esetlegesen végrehajtott módosítások feltüntetésre kerülnek. (SID_1) 